\title{
cuff 法による動脈硬化モデルの作製と薬物の効果*
}

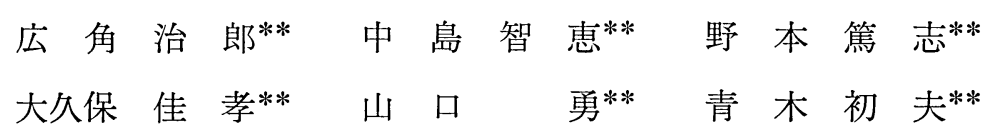

\section{I. 目 的}

現在動脈硬化の原因として，血管内皮傷害をは じめとする平滑筋細胞の役割を重視した「傷害反 応説」が注目されており, 内皮細胞を機械的に直 接傷つけることにより内膜肥厚を伴う動脈硬化像 が得られることが報告されている1). 一方内膜肥 厚を伴う動脈硬化像は, 動脈の外側を cuff で被包 することにより，直接内皮細胞を傷つけることな しに得られることが知られている2 4).

われわれはこの cuff 法による動脈硬化の発生機 序を知る目的で, cuff で被包した血管を組織学的 に観察するとともに, cuff モデルによる薬物の抗 動脈硬化作用の評価の可能性を検討した. 薬物に は当社の Ca 怙抗薬 FR 34235 および, すでに抗 動脈硬化作用の知られている Dexamethasone を 用いた。

\section{II. 材料と方法}

\section{1. 材 料}

体重 $2 \mathrm{~kg}$ の日本白色在来種 ウサギ雄を用い, FR 34235 と Sigma 社の Dexamethasone を使用 した. FR 34235 と Dexamethasone は $0.5 \%$ メチ ルセルロースを含む生理食塩水に䀣濁し， 0.01-10 $\mathrm{mg} / \mathrm{kg}$ 投与した.

\section{2. 動脈硬化作製}

ウサギをネンブタール麻酔下で左総頸動脈を周 辺組織より剝離し, その外側を内径 $2.15 \mathrm{~mm}$, 長 さ $1.5 \mathrm{~cm}$ のポリエチレン製チューブ (BecktonDickenson 社の PE 280)の cuff でわずかな間隙

* 1985 年 1 月, 日本動脈硬化学会 昭和 59 年度冬季 大会において発表

** 藤沢薬品工業株式会社探索研究所
を残して被包した。血管に cuff をはめたままの 状態で普通食にて 1 日から 5 週間飼育した.

\section{3. 薬物投与実験}

cuff 被包対照群 18 匹，無処置の対照群 26 匹， FR 34235 投与群 32 匹, Dexamethasone 投与群 16 匹の 4 群とした. cuff 被包群には溶媒 $(0.5 \%$ メチルセルロースを含む生理食塩水）を投与し, FR 34235 は $0.01,0.1,1,10 \mathrm{mg} / \mathrm{kg}$ を各 8 匹, Dexamethasone は各 4 匹に投与した. 投与期間 は 3 週間とし, 土・日曜を除く週 5 回, 筋肉内に 注射した。

\section{4. 組織学的観察}

血管の横断面切片を作製し, オルセイン染色, または HE 染色して光学顕微鏡下で観察した. 血管内膜表面を観察する場合は, 頸動脈を in situ でヘパリン投与後 $120 \mathrm{mmHg}$ 加圧下にて生理食 塩水で10分間, 続いて $2.5 \%$ グルタルアルデヒドー $0.1 \mathrm{M}$ カコジル酸緩衝液 $(\mathrm{pH}$ 7.4) で 1 時閒灌流 固定した. その後アルコール脱水, 酢酸イソアミ ル置換, 臨界点乾燥, 金一カーボン蒸着を施し, これを走査型電子顕微鏡で観察した.

\section{5. 評 価}

薬物を投与した動物につき, 効果を定量的に判 定するために, 頸動脈の cuff 被包部全域から均 等に約70個の横断面切片を作製した. これを光学 顕微鏡下で観察し, 内膜肥厚度に対応して $0,1,2$, 3 の 4 段階評価を行い, 動物 1 個体の内膜肥厚度 を算出した. 判定規準は $0:$ 正常, 1 : 内膜に弱 い肥厚, $2:$ 内膜全域に肥厚, $3:$ 内膜全域に強度 の肥厚, とした.

\section{III. 成 績}

cuff で被包した血管の経時的な変化を Fig. 1 


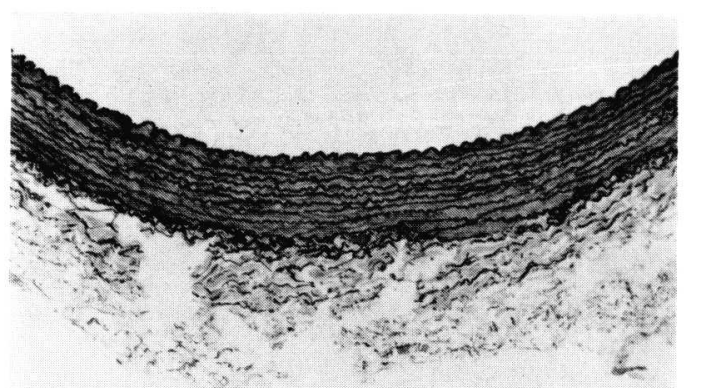

Control

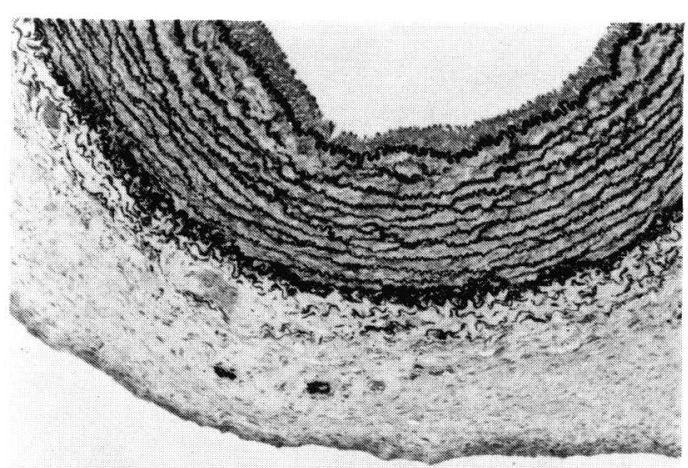

2 weeks

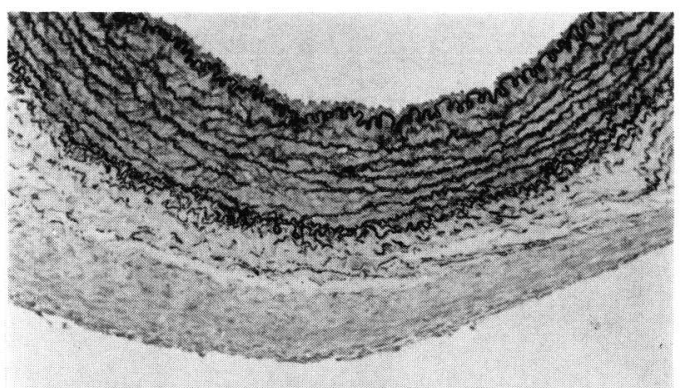

1 week

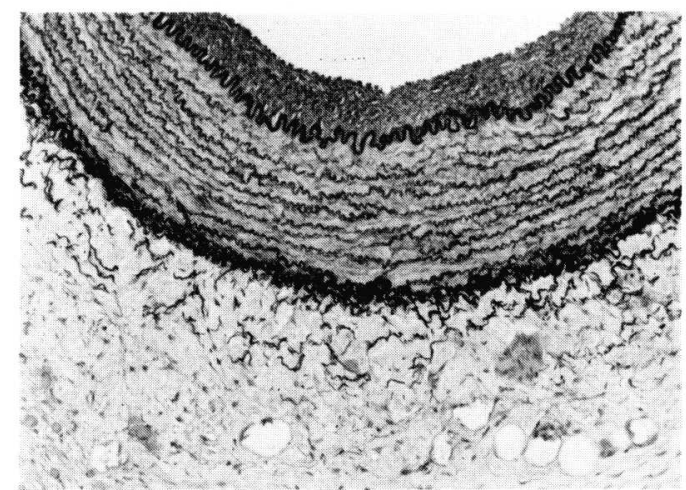

3 weeks

Fig. 1 Intimal thickening after cuff treatment.

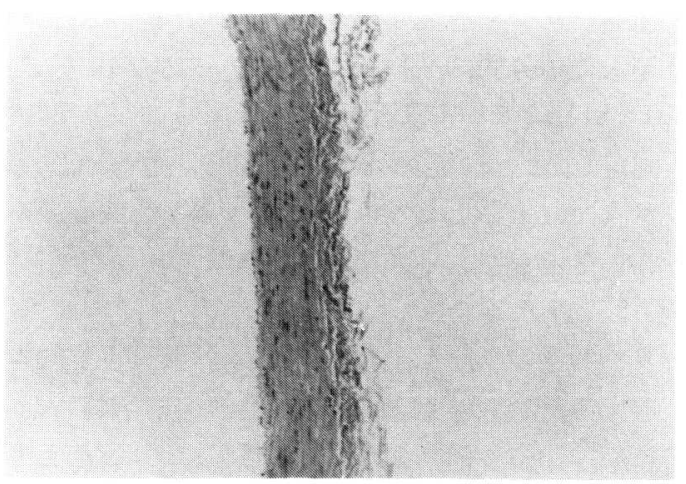

Control

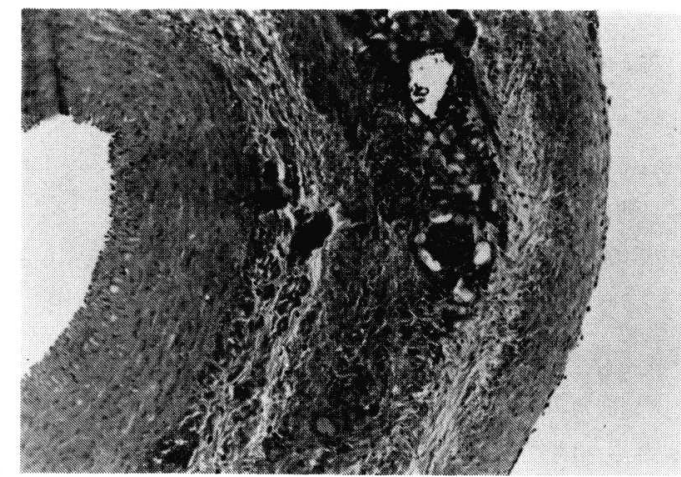

Cuff treated

Fig. 2 Adventitial change after cuff treatment.

(オルセイン染色) に示した。無処置の血管では 内弾性板の上に接して内皮細胞が一層に広がって いる. cuff で被包 (1, 2, 3 週間) した血管では, 内皮細胞と内弾性板の間に増殖した平滑筋様細胞 の層が観察された。また中膜の肥厚, 弾性繊維の
断裂が観察された。これらの変化は経時的に增大 した. 内膜肥厚を経時的にみると 3 週間 cuff で 被包したもので最大となり, 以後は退縮する傾向 がみられた。

Figure 2 に無処置の血管と 3 週間 cuff 被包し 


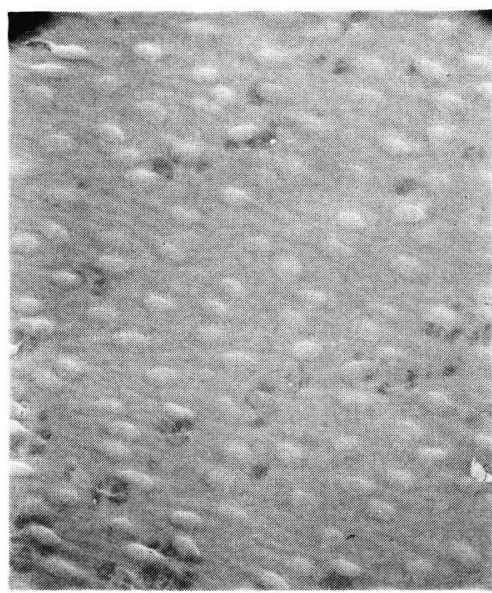

Control $\times 500$

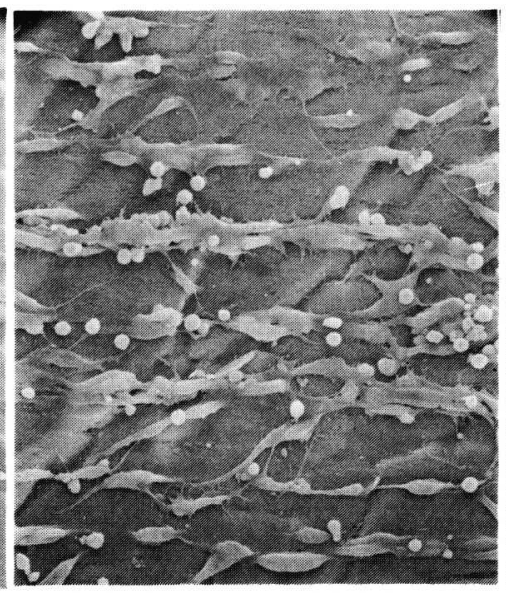

1 day $\times 500$

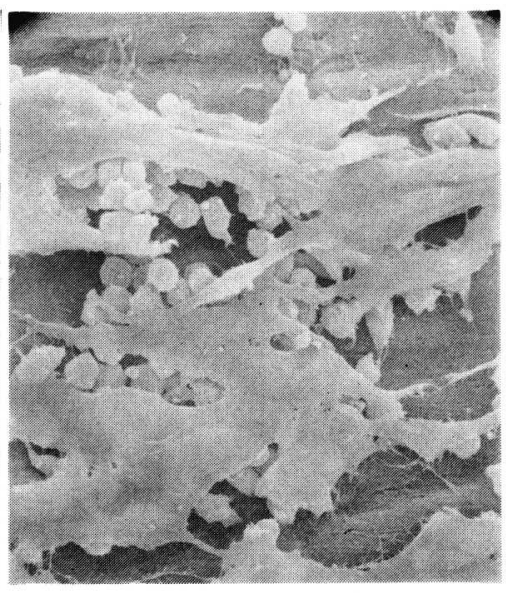

1 day $\times 1000$

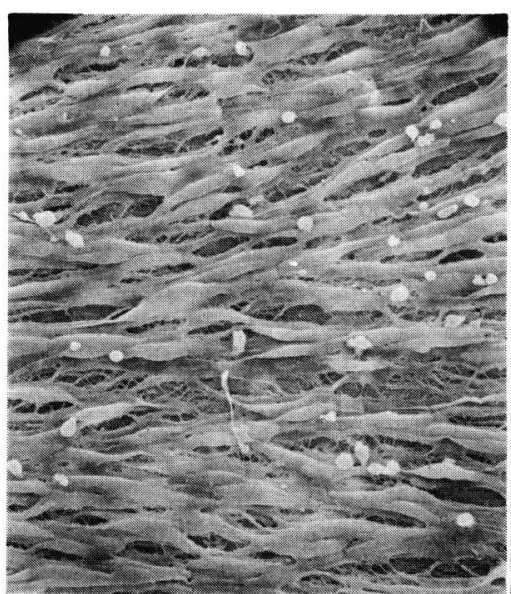

3 days

500

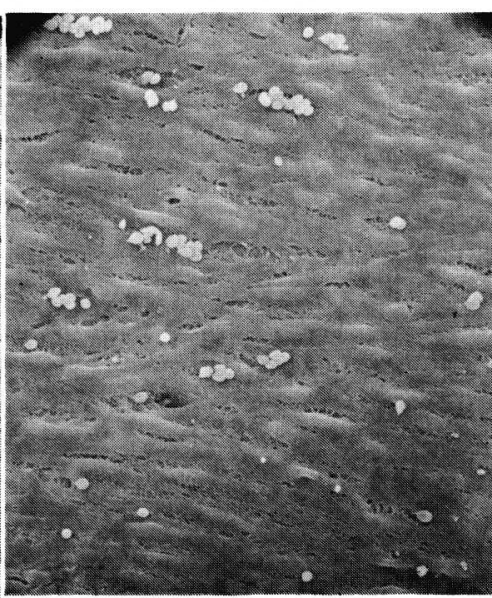

7 days $\times 500$

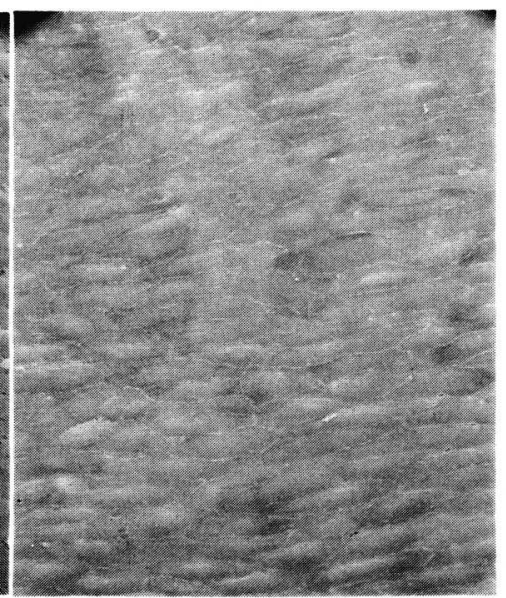

14 days $\times 500$

Fig. 3 Endothelial cell injury after cuff treatment.

た血管を HE 染色で示した．無処置の血管の外膜 は少量の結合組織からなるが，cuff 被包した血管 は外膜の周辺にマクロファージが集合し，fibroblast が増生して肥大している。このような炎症 性変化は cuff 被包 1，2，3 週間のいずれの時期に おいても観察された。

このような動脈硬化性変化の原因を探るため, 内皮細胞の変化を走査型電子顕微鏡で観察した. Fig. 3 に無処置の血管および 1 日，3日，7日， 14 日間 cuff 被包した血管の内皮細胞を示した. 無処置の血管は内腔が伸展した形態の内皮細胞に 㧍㧍われ，血流方向に整然と敷石状に並んでいる. cuff で 1 日被包した血管では内皮細胞が強く傷害
を受けており，残った内皮細胞も収縮していた. このような変化は cuff 被包部全域でみられた。 内皮細胞がはがれたところから内弾性板が露出し， そこに多形核白血球と血小板が付着していた，多 形核白血球は内皮細胞の下にまでもぐり込んでい るところが観察された． 3 日間 cuff 被包したもの では，増殖期にある紡錘形の内皮細胞で一面にお おわれており，修復が進んでいることがわかる. 7 日間 cuff 被包した血管では修復が進み，血管内 腔のほぼ全域が内皮細胞でおおわれているが，ま だ配列の乱れや多形核白血球の付着がみられた。

2 週間以上 cuff で被包したものでは，内皮細胞の 修復が完了しているようにみえる。しかしながら 


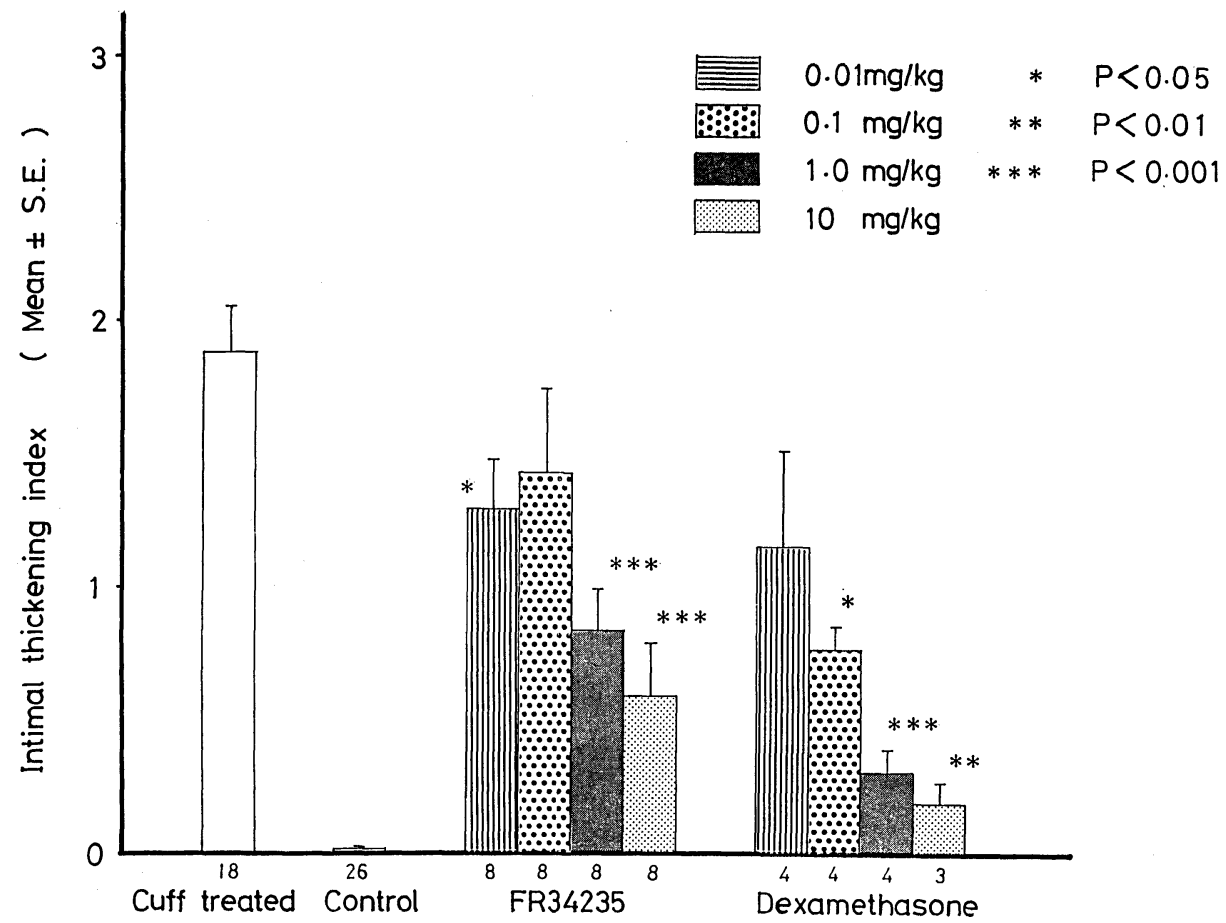

Fig. 4 Effect of drugs on the cuff induced intimal thickening.

この内皮細胞は無処置の血管のものに比べて, cell junction が明瞭で，透過性が変化している可 能性が考えられる.

次にこのモデルによる薬物評価の可能性を検討 するために，抗動脈硬化作用を有する Dexamethasone の投与を行った. Fig. 4 に示すように無 処置の血管の平均内膜肥厚度はほぼ 0 , cuff 被包 血管では約 1.9 であるが，Dexamethasone は用量 依存的に内膜肥厚を抑制し，また外膜の炎症性変 化も消失した. しかし $1 \mathrm{mg} / \mathrm{kg}$ 以上の用量では顕 著な体重減少がみられ，10 mg/kg では 4 匹中 1 匹が死亡した。また FR 34235 も用量依存的に内 膜肥厚を抑制し，中膜肥厚も抑制した。このとき 体重の変化は認められなかった。

\section{IV. 考 察}

組織学的観察の結果, 血管を外側から cuff で 被包すると，まず一過性の内皮傷害がおこり，続 いて外膜の炎症性変化, 平滑筋細胞の増殖をへて, 最終的に内膜肥厚に至るという過程が明らかにな った。
この cuff 法は短期間で形成できる再現性の高 い動脈硬化モデルであり, 抗動脈硬化作用の評価 系として適していることがわかった．今回検討し た FR 34235 はジヒドロピリジンを母核とする $\mathrm{Ca}$ 拮抗薬で, 高血圧などに有效であることが確認さ れているが，抗動脈硬化作用をもつことが示唆さ れた。

\section{文献}

1) Helin, P., Lorenzen, I., Garbarsch, C. and Matthiessen, M. E.: Arteriosclerosis in rabbit aorta induced by mechanical dilatation. Atherosclerosis, 13: 319-331 (1971).

2) Huth, F., Kojimahara, M., Franken, T., Rhedin, P. and Rosenbauer, K. A.: Aortic alterations in rabbits following sheathing with silastic and polyethylene tubes. In: Grundmann, kirsten (eds) Current topics in pathology, Vol. 60, Springer, Berlin, Heidelberg, New York, pp. 1-32 (1975).

3) 水川秀海：動脈硬化症の成り立ちに関する実験病理 学的研究. 北関東医学, 19 (5): 475-496 (1969).

4) 北村徳治 : 動脈硬化症における内膜肥厚の初期変化 に関する電子顕微鏡的研究. 金沢大学十全医学会雑 誌, 19 (5): 876-889 (1982). 


\title{
Summary
}

\section{Preparation of Atherosclerotic Model by the Cuff Method and Effects of Drugs on the Atherosclerosis}

\author{
Jiro Hirosumi, Chie NaKajima, Atsushi Nomoto, \\ Yoshitaka OHкUBo, Isamu YAMAGUCHI and Hatsuo AoKI
}

The Exploratory Research Laboratories, Fujisawa Pharmaceutical Co., Ltd.

In order to clarify the mechanisms underlying atherogenesis, we studied effects of drugs on the arterial intimal thickening induced in rabbits by the cuff method. Under pentobarbital anesthesia, the carotid artery was sheathed with a cuff made of a polyethylene tube $(1.5 \mathrm{~cm}$ long PE-280). Animals were given normal diet and water ad lib., and i.m. drugs 5 times a week for 3 weeks. After sacrifice, their sheathed arteries were observed histologically. Although non-treated arteries had no intimal thickening, smooth muscle cells appeared in the intima after the cuff-treatment. Intimal thickening increased gradually and reached its peak 3 weeks after the cuff-treatment, and it shrank thereafter. Inflammatory changes were observed in the adventitia throughout the experimental period.

Scanning electron microscopy revealed endothelial injury after the cuff-treatment. A number of leukocytes and platelets adhered to the exposed internal elastic laminae 1 day after the cuff-treatment. Injured endothelium began to repair within 3 days, and almost complete recovery from the damage was attained 2 weeks thereafter. Dexamethasone inhibited both intimal thickening and adventitial inflammation in a dose-dependent manner $(0.01-10 \mathrm{mg} / \mathrm{kg})$, but more than $1 \mathrm{mg} / \mathrm{kg}$ of dexamethasone made animals thin remarkably. A calcium antagonist FR34235 inhibited the intimal thickening in a dose-dependent manner $(0.01-10 \mathrm{mg} / \mathrm{kg})$, and had no effect on animals' weight. These results suggest that passing endothelial injury and adventitial inflammation are involved in the atherogenesis by the cuff-treatment, and this method is a suitable model to estimate antiatherogenic effect of drugs. A calcium antagonist FR34235 is expected to be an antiatherogenic agent.

Key words: cuff method, intimal thickening, endothelial injury, dexamethasone, FR34235. 